orifices have been acquired among Lepidoptera, Strepsiptera and in the Hemipterous family Cimicidæ. The postulation of a change from a progoneate to an opisthogoneate condition refers, therefore, to the evolution of a class wherein diverse modifications of the genital conduits are a prominent feature. The Insecta are peculiar in that the egg-follicles are disposed in a linear series forming ovarioles, while at the apex of each ovariole is an end-chamber (or germarium) containing the undifferentiated germ cells. In other arthropods no such arrangement into ovarioles prevails and the germarium is located parietally. It will be evident that structural modifications of the gonads must have been involved during the evolution of the Insecta, and, it is claimed, that these changes occurred in association with the development of posterior gonoducts.

So far, the Protura and Collembola have been omitted from discussion : they are side developments off the main line of insect descent. The Protura show a predominance of hexapod features, suggesting that the early evolution of this group was with the rest of the Insecta. Afterwards they diverged as a specialized side branch but retained the primitive trait of anamorphosis. The Collembola display both myriapodan and insectan characters. Owing, possibly, to the paucity of yolk, which has induced holoblastic segmentation, development became arrested and only nine trunk segments formed. In the absence of ovarioles and retention of the parietal germarium, together with the general simplicity of the gonads, the Collembola betray close resemblances to the Symphyla. The possibility that traces of a former progoneate ancestry are revealed in Collembola, as mentioned by Claypole ${ }^{4}$, needs further investigation ; evidence of such ancestry also requires exploration among other Apterygota.

Re-examination of the symphylan theory seems, therefore, to establish it as the only adequate explanation of insect descent. In view of the many fundamental similarities between the Symphyla and Thysanura, it is claimed that these two groups arose from a common stock, not very different from living forms of Symphyla. Theories involving separate origins for the two groups in question, on the grounds of disparity in the segmental locations of the gonopores, have to fall back upon the improbable hypothesis of convergence to account for their community of structure. If the propositions now advanced serve to focus attention upon aspects of the problem hitherto neglected, they will have fulfilled their purpose.

\footnotetext{
${ }^{1}$ Ann. della Scuola Sup. di Agric. in Portici, 5 (1903) ; ibid., 6 (1905). 2 Packard, "Text-book of Entomology", 22 (1898).

s Pap. Roy. Soc. Tasm., 1930 ; and NATURe, 126 (1930); this theory was partially recast in Amer. $J$. Sci., 30, 438 (1935).
}

4. Morph., 14, 239 (1898).

\title{
The Recent Floods in the United States*
}

\author{
By Dr. C. E. P. Brooks
}

$\mathrm{T}^{\mathrm{H}}$ HE Mississippi and its tributaries together drain about half the area of the United States. The Mississippi itself runs through the centre of the country, the Missouri rises in the Rocky Mountains and the Ohio in the Allegheny Mountains. The upper courses of the Mississippi and Missouri lie in relatively dry regions, where moreover the winter precipitation is mainly in the form of snow. The Ohio, on the other hand, runs through a region of comparatively heavy rainfall, and is much more liable to flooding.

During the last few months of 1936 , the rainfall in the valley of the Ohio and the Mississippi above Memphis had been abnormally heavy, the total for the months September-December being nearly one and a half times the normal. Thus at the beginning of January, the ground was waterlogged and there was already minor flooding in some of the tributaries of the Ohio. In January

\footnotetext{
- Paper read before the Royal Meteorological Society on February 17.
}

a type of pressure distribution developed which was very favourable to prolonged heavy rain (Fig. 1). Pressure was high off the east coast of the United States, and decreased steadily westwards. This was associated with a current of warm moist air blowing from the Caribbean Sea and the Gulf of Mexico across the eastern half of the United States. Above this warm and very moist south-easterly wind was an upper current from the west, which was relatively cool. The air was therefore highly unstable. Farther north, over the Great Lakes and southern Canada, pressure decreased northward, and the westerly current descended to ground-level. The encounter of the warm moist south-east wind with this great barrier of colder air from the west gave all the conditions necessary for heavy and prolonged rain, which was localized by a series of depressions travelling from south-west to north-east along or near the line of the Ohio Valley. 
The rainfall was abnormally heavy, exceeding four times the January normal between Cincinnati and Cairo, the totals for the three weeks January 6-26 reaching 12 inches at Cincinnati and 16 inches at Louisville farther down the Ohio*. The latter river rose steadily along its whole length, the rise being hastened by the abnormally high temperatures, which prevented any accumulation of snow or ice. The main stream of the Ohio was in flood on January 10, and by January 19 the floods were general. From that date conditions rapidly became disastrous. The official "flood stage" at Cincinnati is a level of 52 feet, and the highest level on record was $71 \cdot 1$ feet, which occurred on February 14, 1884. This record was passed on January 23, and on January 26 the level stood at 80 feet. Previous records were exceeded at all stations on the Ohio below Parkersburg, and on the Mississippi from Cairo to at least Memphis.

The crest of the flood reached Cairo, at the junction of the Ohio and Mississippi, early in February, the highest level being about 60 feet. This is nearly four feet higher than the highest crest of the great flood of 1927, which itself constituted a record. The defences of Cairo have, however, been greatly strengthened during the past ten years, and although the city was isolated and abandoned by most of the inhabitants, it did not suffer so severely as in 1927. It lay precariously in a hollow surrounded by water up to the level of the house-tops, and some damage was caused by

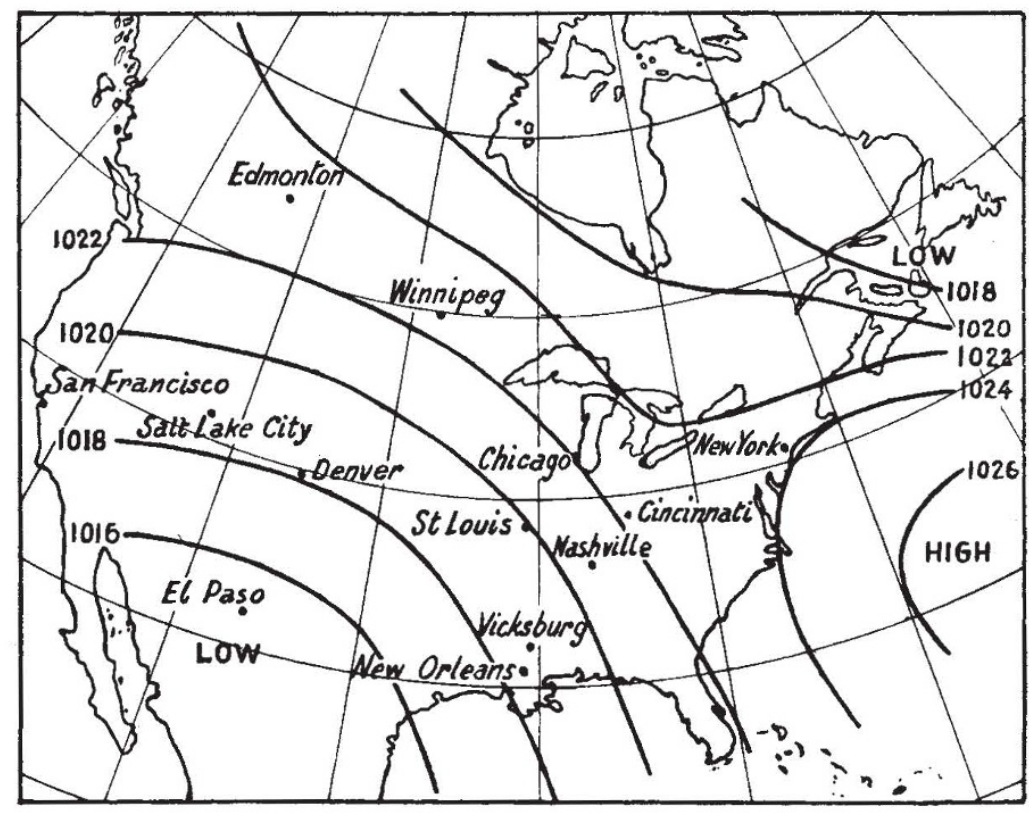

Fig. 1.

Distribution of Pressure over the United States in Jandary, breaking its banks. On February 10 the level at previous record. After that date, however, the levels began to fall steadily and no further danger was anticipated. mainly in the area of greatest damage, which was limited to the Ohio valley instead of extending widely over the whole Mississippi below Cairo. In 1927 the Ohio valley was much less affected than in some earlier floods, especially those of 1883 and 1907. The Ohio valley is narrower and steeper than that of the lower Mississippi, and the Ohio floods both set in and pass away comparatively more than two feet higher than in 1927 , without Helena, Arkansas, was about three feet above the

The flood of 1937 differed from that of 1927 water forcing its way through an

underlying bed of sand and coming up in sudden 'sand-boils'. Farther down the Mississippi, the chief danger areas are along the tributaries entering the main river below the Ohio. These cannot be completely protected by levees, and the water floods back up them, and over the surrounding country. As a measure of precaution, tínousands of people were evacuated from their homes along these tributaries in Arkansas, Louisiana and Mississippi.

By about February 5, the cities of the Ohio Valley were able to resume normal activities and the level had begun to fall at Cairo. The flood crest was now making its way slowly down the main Mississippi; but the levees were being strengthened at all danger spots, and the engineers were confident that they would hold. On February 9 the river at Memphis reached a level of 48.7 feet,

- Sea map in Natdre, Feb. 6, 1937, p. 227. 
ignited, and there were several outbreaks of fire. About a million people were homeless, and though the loss of life was probably not more than five hundred, the material damage amounted to hundreds of millions of pounds.

The meteorologists at least have not been found wanting, and it is fitting to conclude this brief account with a reference to the work of the United States Weather Bureau. The forecasts of the times and heights of flood stages were of incalculable assistance throughout to the patrols and rescue organizations. Without these warnings, the loss of property, and still more of life, would have been enormously greater.

\section{News and Views}

\section{Prof. J. Stanley Gardiner, F.R.S.}

THE retirement of Prof. Stanley Gardiner from the chair of zoology and comparative anatomy in the University of Cambridge next October will bring to an end a remarkably interesting and important period in the history of the Department of Zoology at Cambridge. At the time of his appointment, Prof. Gardiner was a leading authority on marine zoology, with a specialist's knowledge of the systematics of corals. He had gained a wide knowledge of the methods used in the exploration of the sea during the times when he took part in expeditions to the Pacific and Indian Oceans. As a result, he has been able to give most important and valuable advice and assistance to all the British expeditions for scientific oceanography from the time of his appointment to the present day. But Prof. Gardiner is a naturalist, and his extensive interests in animals and plants have given him a wide sympathy for all branches of scientific research in zoology, and therefore when the dream of an adequate zoological institute in the University became true, he saw to it that every aspect of the subject was fully provided for. The very large number of his former pupils will remember with gratitude the personal interest he took in their work, and the kindly advice and help he gave them at the outset of their careers.

\section{Dr. J. Gray, F.R.S.}

Prof. Stanley Gardiner will be succeeded by Dr. James Gray, who was one of his pupils when he became professor in 1909. Dr. Gray has had a varied career. $\mathrm{He}$ was demonstrator of zoology before the Great War, carrying out research on fertilization of echinoderm eggs. Then he saw war service from August 1914 until the peace, serving in France and Palestine, attaining the rank of captain and being awarded the M.C. Returning to Cambridge, he became Balfour student, commencing a long line of research on ciliary movement, in which he and his pupils are still interested. Lecturer and reader in turn, by a natural evolution he passed onwards to a comprehensive study of the physiology of animal locomotion, being especially interested in fish. In 1928, he was visiting professor at Columbia University. His share in the rebuilding of the whole Zoological
Department at Cambridge was great, and in particular he was charged with the design of the experimental section, which contains, besides a teaching laboratory, twenty-five separate research rooms and at present overflows into the whole building. Elected to the Royal Society in 1929, he is now a member of the Council. $\mathrm{He}$ is also a member of the Advisory Committee on Fisheries of the Development Commission, but perhaps his greatest public service to science is in the editing of the Journal of Experimental Biology, which is associated with the Society of the same name.

\section{Inauguration of an Ultra-centrifuge at Oxford}

A Svedberg ultra-centrifuge, generously lent to the University of Oxford by the Royal Society and erected in the Department of Biochemistry (Prof. R. A. Peters), was formally set going on February 27 in the presence of a large company by the ViceChancellor of the University, the president of the Royal Society and Prof. The Svedberg of Uppsala himself. The cost of the complete instrument, defrayed by the Royal Society, was $£ 2,000$. The cost of its erection has been met by the University. It is one of five similar instruments, the third outside Sweden-two are at Uppsala, one in London at the Lister Institute of Preventive Medicine, and another in the United States. It is designed for the determination of the rate of sedimentation of particles of very high molecular weights. The rotor, of a nickelchromium steel found after many trials to stand the great strain put upon it, is supported by bearings of Babbitt's metal and driven by two small oil turbines, one at each end of the shaft, which give a smooth and easily regulated run. The rotor moves in an atmosphere of hydrogen of about $25 \mathrm{~mm}$. pressure. Rotation speeds, determined electrically, up to 65,000 revolutions per minute (equal to about 300,000 times gravity) can be safely attained. The solution to be centrifuged is contained as a thin column in a cell with quartz windows carried, and suitably balanced, on the rotor. The height of the column, which is about $7 \mathrm{~cm}$. from the centre of rotation, does not generally exceed $27 \mathrm{~mm}$. The position of the moving boundary of the particles sedimented during a run of the ultra-centrifuge is determined from photographs obtained at suitable 